\title{
Review \\ Intrinsic and Extrinsic Factors Impacting Cancer Stemness and Tumor Progression
}

\author{
Alexey Ponomarev ${ }^{1}$, Zarema Gilazieva ${ }^{1}$, Valeriya Solovyeva ${ }^{1}$, Cinzia Allegrucci ${ }^{2} \odot$ and Albert Rizvanov ${ }^{1, *}$ \\ 1 Institute of Fundamental Medicine and Biology, Kazan Federal University, 420008 Kazan, Russia; \\ alesponomarev@stud.kpfu.ru (A.P.); zaregilazieva@kpfu.ru (Z.G.); vavsoloveva@kpfu.ru (V.S.) \\ 2 School of Veterinary Medicine and Science (SVMS) and Biodiscovery Institute, University of Nottingham, \\ Nottingham NG7 2RD, UK; cinzia.allegrucci@nottingham.ac.uk \\ * Correspondence: albert.rizvanov@kpfu.ru
}

check for updates

Citation: Ponomarev, A.; Gilazieva, Z.; Solovyeva, V.; Allegrucci, C.; Rizvanov, A. Intrinsic and Extrinsic Factors Impacting Cancer Stemness and Tumor Progression. Cancers 2022, 14, 970. https://doi.org/10.3390/ cancers14040970

Academic Editor: Rob P. Coppes

Received: 24 December 2021

Accepted: 8 February 2022

Published: 15 February 2022

Publisher's Note: MDPI stays neutral with regard to jurisdictional claims in published maps and institutional affiliations.

Copyright: (C) 2022 by the authors. Licensee MDPI, Basel, Switzerland. This article is an open access article distributed under the terms and conditions of the Creative Commons Attribution (CC BY) license (https:// creativecommons.org/licenses/by/ $4.0 /)$.
Simple Summary: Presently, the study of cancer stem cells is important because these cells increase the cancer complexity, confer tumors the ability to grow, resist treatment, and survive in adverse conditions. One of the properties that these cells have is stemness. Cancer stemness is modulated by the tumor microenvironment, which influences cancer stem cell function and survival. This review includes information about cancer stem cells and their regulation by extrinsic and intrinsic factors. Pluripotency factors and signaling pathways, which regulate and modulate cancer stemness are summarized in this review. In addition, it provides an overview of the models that allow the study of cancer stem cells for the development of new targeted therapies.

\begin{abstract}
Tumor heterogeneity represents an important limitation to the development of effective cancer therapies. The presence of cancer stem cells (CSCs) and their differentiation hierarchies contribute to cancer complexity and confer tumors the ability to grow, resist treatment, survive unfavorable conditions, and invade neighboring and distant tissues. A large body of research is currently focusing on understanding the properties of CSCs, including their cellular and molecular origin, as well as their biological behavior in different tumor types. In turn, this knowledge informs strategies for targeting these tumor initiating cells and related cancer stemness. Cancer stemness is modulated by the tumor microenvironment, which influences CSC function and survival. Several advanced in vitro models are currently being developed to study cancer stemness in order to advance new knowledge of the key molecular pathways involved in CSC self-renewal and dormancy, as well as to mimic the complexity of patients' tumors in pre-clinical drug testing. In this review, we discuss CSCs and the modulation of cancer stemness by the tumor microenvironment, stemness factors and signaling pathways. In addition, we introduce current models that allow the study of CSCs for the development of new targeted therapies.
\end{abstract}

Keywords: oncological diseases; cancer stem cells; stemness; spheroids; drug screening; tumor microenvironment

\section{Introduction}

Cancer stem cells (CSCs) are a population of cells present in malignant tumors that share many similarities with normal stem cells or progenitor cells. The common characteristics of these cells include the ability to self-renew and differentiate into multiple lineages, leading to activation of tumor growth and heterogeneity. Mutations that occur in the stem cell pool may contribute to the process of oncogenesis [1]. In addition, there is a link between aging and an increase in the incidence of cancer. There is an accumulation of damage that can lead to the inactivation of tumor suppressor genes and the activation of oncogenes with aging [2]. The origin of CSCs remains unclear, as well as whether they originate from normal stem cells or non-stem cells through re-acquisition 
of stem cell traits (stemness) through a change in differentiation [3-5] (Figure 1). CSCs are generally a rare population of cells, usually amounting to $0.01-2 \%$ of the total tumor mass. A notable exception to this evidence is represented by malignant melanoma which comprises a high proportion of CSCs [6]. CSCs share many characteristics with their normal counterparts, including expression of surface markers and regulation by common signaling pathways [7-9]. Most CSC surface markers (Table 1) are expressed by embryonic or adult stem cells and are rarely expressed by normal differentiated tissue cells [10]. The expression of surface markers is used to identify and isolate CSC s by fluorescence-activated cell sorting (FACS) and magnetic-activated cell sorting (MACS) [11,12]. Additionally, for the isolation and enrichment of CSCs, the following methods are used: intracellular enzyme activity, promoter-driven fluorescent protein expression, suspension/adherent culture, immunoselection, etc. [13]. However, CSC markers can be characterized not only by the expression of surface markers, but also by intrinsic and extrinsic factors which include transcription factors, microRNAs (for example, miR-21, miR-210, miR-34a, and miR-16) [14], signaling molecules [15-17], and extracellular matrix (ECM) [18].

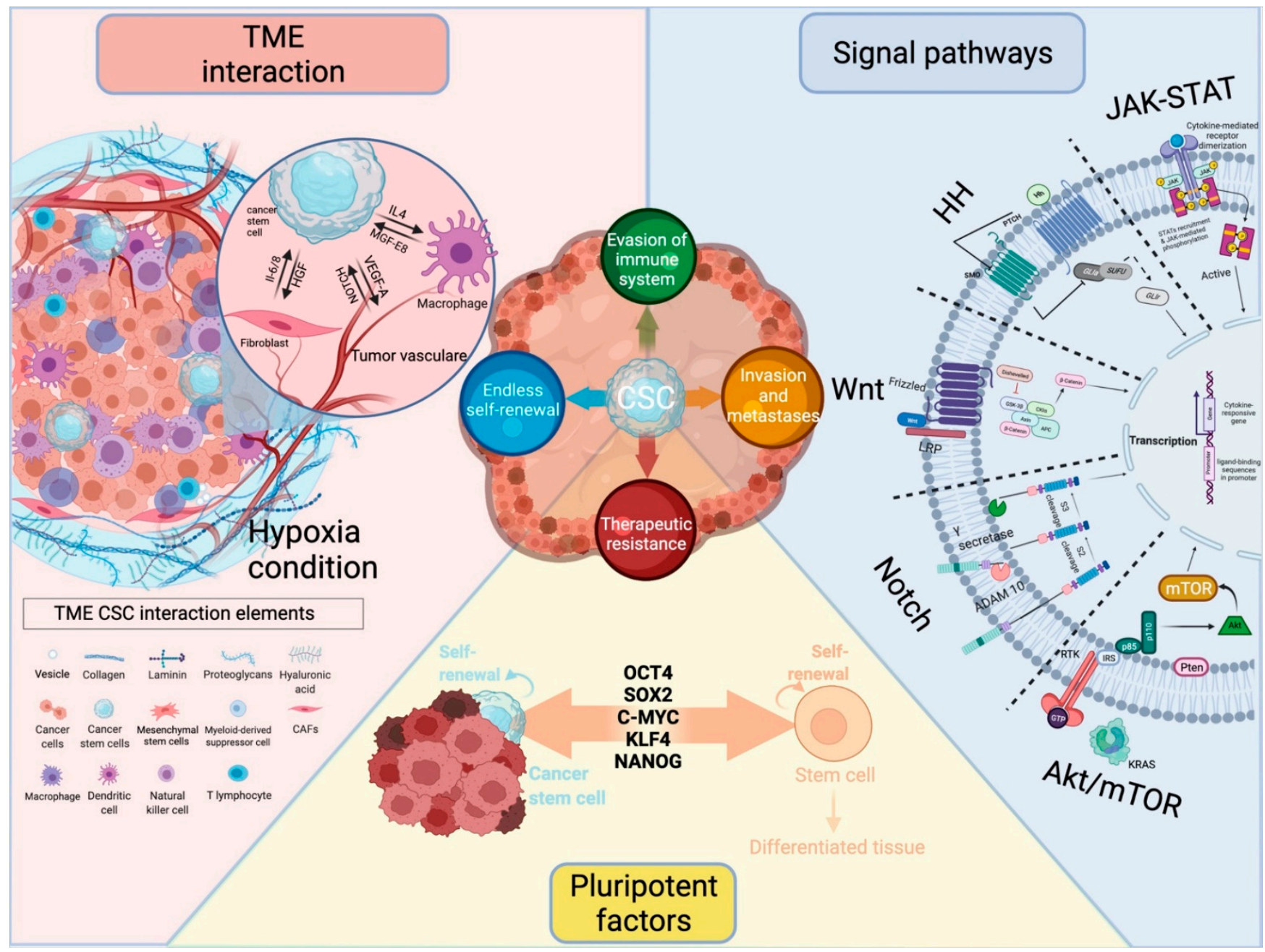

Figure 1. CSCs and the modulation of cancer stemness by the tumor microenvironment, stemness factors, and signaling pathways. Impact of CSCs on tumor progression, recurrence, and resistance to therapy. Created with BioRender.com (accessed on 22 December 2021). 
Table 1. CSCs markers in different types of tumors.

\begin{tabular}{|c|c|c|}
\hline Cancer Type & CSCs Markers & Reference \\
\hline Blood tumors & $\mathrm{CD} 4^{+} \mathrm{CD} 38^{-}$phenotype & [19] \\
\hline Brain tumors & 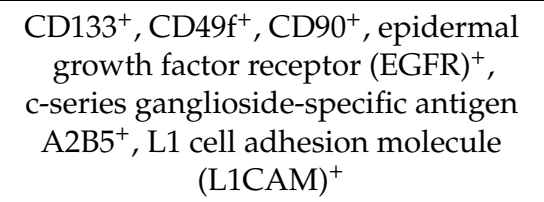 & [20-22] \\
\hline Ovary tumors & $\begin{array}{c}\mathrm{CD} 24^{+}, \text {aldehyde dehydrogenase } \\
(\mathrm{ALDH})^{+}, \mathrm{CD}^{+} 4^{+} / \mathrm{CD} 117^{+}, \text {epithelial } \\
\text { cell adhesion molecule }(\text { EpCAM })^{+} \\
{\mathrm{CD} 133^{+}}\end{array}$ & {$[23,24]$} \\
\hline Prostate tumors & $\begin{array}{c}\text { EpCAM }^{+}, \mathrm{CD}_{117^{+}}, \alpha 2 \beta 1 \text { integrin } \\
\mathrm{ALDH}^{+}, \\
\mathrm{CD}^{+} 4^{+}, \text {enhancer of zeste } \\
\text { homolog }(\mathrm{EZH})^{+}, \mathrm{CXC} \text { chemokine } \\
\text { receptor type } 4(\mathrm{CXCR} 4)^{+}, \\
\text {E-cadherin }^{+}, \mathrm{CD} 133^{+}\end{array}$ & {$[13,25,26]$} \\
\hline Colon tumors & $\begin{array}{c}\mathrm{CD} 133^{+}, \mathrm{CD}^{2} 4^{+}, \mathrm{CD} 166^{+}, \mathrm{CD}^{+} 4^{+}, \\
\left.\mathrm{EpCAM}^{+}\right)\end{array}$ & [27-30] \\
\hline Pancreatic tumors & $\begin{array}{l}\mathrm{CD} 133^{+}, \mathrm{CD}_{4}{ }^{+}, \mathrm{CD}^{+} 4^{+}, \mathrm{EpCAM}^{+}, \\
\text {tyrosine-protein kinase Met }(\mathrm{cMet})^{+}\end{array}$ & {$[31,32]$} \\
\hline Liver tumors & $\begin{array}{l}\mathrm{CD} 44^{+}, \mathrm{CD}^{+} 0^{+}, \mathrm{CD}^{206}{ }^{+}, \text {oval cell } \\
\left.\text { antigen } 6(\mathrm{OV}-6)^{+}\right), \text {skin }\left(\mathrm{CD} 20^{+},\right. \\
\mathrm{CD}^{\prime} 71^{+}, \mathrm{ALDH}^{+}, \mathrm{CD}^{\prime} 33^{+}\end{array}$ & [33] \\
\hline Lung tumors & $\begin{array}{c}\mathrm{CD} 133^{+}, \mathrm{ATP}-\text { binding cassette } \\
\text { super-family G member } 2 \\
(\mathrm{ABCG} 2)^{\text {high }}, \mathrm{CD} 166^{+}, \mathrm{CD} 90^{+}, \mathrm{CD} 87^{+}, \\
\mathrm{ALDH}^{+}, \mathrm{CD}^{+} 4^{+}\end{array}$ & [34] \\
\hline Breast tumors & 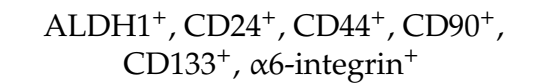 & [35-38] \\
\hline
\end{tabular}

All of these factors regulate CSC function, under the influence of the tumor microenvironment (TME). Differently from normal stem cells, whose proliferation is finely regulated by interactions with their physiological niche, CSCs demonstrate abnormal regulation of self-renewal that enables their expansion either by symmetrical or asymmetrical cell division [7]. Differences between the niche surrounding normal cells and CSCs are at the basis of CSCs ability to transition into different cell states, to remain dormant for long periods of time, and to metastasize to different sites [39]. The niche is a specialized microenvironment that regulates normal stem cell function through cell-to-cell interaction and paracrine signaling. Escape of normal stem cells from control of proliferation and apoptosis provided by the niche is associated with malignant transformation and the formation of a "CSC niche" which induces the recruitment of cells of the TME (mesenchymal stem cells (MSC), immune cells, endothelial cells, and tumor associated fibroblasts (TAF)), secreting growth factors and cytokines essential for sustaining CSC self-renewal [40,41]. By maintaining differentiation capacity, CSC can then lead to the formation of heterogeneous tumors characterized by the growth of phenotypically different subclones [42] of transit-amplifying cells which accumulate and accelerate tumor growth [3]. These heterogeneous cell populations demonstrate high plasticity potential $[43,44]$ and high resistance to stressful factors present in the TME, such as low oxygen or lack of nutrients [39,45].

The CSC niche therefore supports the basic properties of CSCs, preserves their phenotypic plasticity, protects them from the immune system, and contributes to their metastatic potential [39]. Key to the CSC plasticity and metastatic potential is the process of epithelialmesenchymal transition (EMT) [46,47]. EMT can be induced by the cells of the TME secreting cytokine (e.g., TGF $\beta$ and interleukins) to causes changes in cytoskeleton organiza- 
tion, loss of apical-basal polarity, expression of E-cadherin, and acquisition of mesenchymal features and motility, as well as remodeling of the extracellular matrix (ECM) $[48,49]$. Through these changes, EMT induces a CSC phenotype which enables tumor metastasis and confers resistance to therapy [50-52]. It should be emphasized that metastasis is associated with circulating tumor cells that originate from the primary tumor, but these cells have properties of stemness and EMT, which contribute to their penetration and circulation in the blood and increased metastatic ability [53].

Indeed, CSCs are inherently resistant to radiation and cytotoxic drugs, and therefore responsible for minimal residual disease and cancer recurrence [54]. Currently, the study of cancer stemness poses a number of questions, which include: how different are CSCs from normal stem cells; are CSC properties changing during the course of disease; are there differences in stemness between different cancer subtypes; how CSC knowledge can be used to advance precision medicine [55].

In this review, we discuss cancer stemness, CSCs, and their regulation by extrinsic and intrinsic factors. Stemness can be affected by both physical and chemical factors. The main attention of this article is focused on chemical factors, molecular pathways of CSC interaction, and their microenvironment. A deeper understanding of the interactions between CSCs and the microenvironment, including the mechanisms responsible for switching cancer cells from non-CSC to CSC status, is essential for the discovery of effective new therapies. In addition, knowledge about extrinsic and intrinsic factors and their influence on stem formation can provide targeted therapy as well as prevent cancer recurrence and metastasis.

\section{Pluripotency Factors as Intrinsic Factors Regulating Cancer Stemness}

CSC function is determined by a dysregulation of stemness-related signaling pathways. A reduced level of tumor differentiation and increased self-renewal are a characteristic of stemness. Transcription factors which are master regulators of self-renewal and pluripotency in embryonic stem cells (ESCs) have been demonstrated to play a key role in the regulation of stemness in cancer [56]. These transcription factors include the octamer-binding transcription factor 4 (OCT4), the sex-determining region Y-box 2 (SOX2), the homeobox transcription factor NANOG, the Kruppel-like factor 4 (KLF4), and the proto-oncogene C-MYC [57-59].

Expression of these factors can reprogram somatic cells into induced cancer stem cells and promote cell plasticity allowing cancer cells to adapt, survive, grow, and resist therapies. This effect has been demonstrated by a recent study showing acquisition of stemness after induced expression of OCT4, SOX2, and NANOG and high expression of pluripotency genes in advanced prostate, bladder, and renal cancers which was correlated with aggressive disease and drug resistance [60]. In addition, pluripotency factors have been shown to mediate cell plasticity in the TME and of enhance ECM production leading to metastasis [61]. Expression of pluripotency factors also regulate the expression of EMT mediators SNAI1 and SNAI2 [62].

Ectopic expression of OCT4 induced a block of differentiation and dysplasia in epithelial tissues $[63,64]$. Expression of OCT4 has been found in several cancer types and it contributes to the self-renewal and chemoresistance of CSCs $[65,66]$. Indeed, OCT4 induces the expression of the drug transporter ABCG2, which is highly expressed in CSCs and responsible for drug resistance [67]. Moreover, a relationship between OCT4 translation and metastasis of colorectal cancer to the liver have been demonstrated [68]. Similarly, it has been shown that OCT4 expression in lung cancer cells promotes the polarization of M2 type macrophages due the macrophage colony-stimulating factor (M-CSF) secretion, which leads to increase in tumor growth and metastasis [69].

SOX2 expression is also associated with cancer stemness [70,71]. Expression of this transcription factor is increased in cells and tumor tissue of patients with triple-negative breast cancer (TNBC). Importantly, inhibition of SOX2 suppresses proliferation and invasion of breast cancer cells, inducing cell apoptosis in vitro and inhibiting tumor growth and 
metastasis in vivo [72]. SOX2 knockout in a mouse model of osteosarcoma also induces a sharp decrease in frequency and occurrence of tumors [73]. In addition, SOX2 and CD133 co-expression can be associated with poor outcome in colon, stomach, and ovarian cancers, as well as melanoma and advanced cancers with bone metastases [74].

NANOG is also involved in maintaining embryonic stem cell self-renewal and cancer stemness [75-77]. It has been shown that an increase in the number of oral cancer stem-like cells is associated with increase expression of NANOG and increase malignancy [78]. The expression of this transcription factor increases with the degree of dysplasia and is an early predictor of cancer risk in patients with oral cavity malignant diseases [79]. Mutation in the tumor suppressor SPOP and negative regulator of NANOG also leads to increased stemness of prostate cancer and a negative prognosis in prostate cancer [80]. Dehghan Harati et al. have shown that the expression of NANOG is associated with the increased activity of ALDH and radioresistance, as well as with repair of double-strand DNA breaks [81].

Together with other pluripotency genes, KLF4 plays an important role in the regulation of cell growth, proliferation, and differentiation [82]. In embryonic stem cells, KLF4 activates the expression of telomerase reverse transcriptase (TERT) and contributes to the maintenance of self-renewal [83]. In cancer, KLF4 can act either as oncogene by inhibiting apoptosis or tumor suppressor by inducing p21-dependent cell cycle arrest. For instance, KLF4 is highly expressed in a subset of human melanomas and ectopic KLF4 expression enhances melanoma cell growth by decreasing apoptosis [84]. It has also been shown that KLF4 expression is associated with stemness of osteosarcoma [85]. However, KLF4 can also function as tumor suppressor and its knockdown can promote migration and invasion of non-small-cell lung carcinoma (NSCLC) [86].

Similarly, enhanced expression of KLF4 by lentiviral transduction increased sensitivity of ovarian cancer cells to the chemotherapeutic drugs paclitaxel and cisplatin [87].

Finally, C-MYC coordinates various biological processes in stem cells, such as cell cycle, cell metabolism, self-renewal, differentiation, and apoptosis [88]. Mutations in MYC genes have been found in many tumors and C-MYC is upregulated and acts as an oncogene in more than 50\% of human cancers [89]. The expression of C-MYC correlates with the level of differentiation in cancer, as expression of C-MYC induces de-differentiation and acquisition of CSC properties, including glutamine metabolic addiction, dormancy and therapeutic resistance [90]. Dysregulation of MYC usually plays an important role in maintaining the number of invasive CSCs. For example, increased expression of MYC is associated with glioblastoma CSC-induced cell proliferation and invasion, and apoptosis inhibition [91].

\section{Signaling Pathways Modulate Cancer Stemness}

Several signaling pathways that are known mediators of juxtacrine (cell-cell) and paracrine extracellular signaling in the local TME have been identified to be key extrinsic players in the regulation of cancer stemness. These include Wnt, Notch, Hedgehog (Hh), Janus kinase/signal transducers and activators of transcription (JAK/STAT), and phosphatidylinositol 3-kinase/serine/threonine-protein kinase/mammalian target of the rapamycin (PI3K/AKT/mTOR) (reviewed in detail in Yang et al.) [56]. Moreover, some of these pathways also participate in epithelial-to-mesenchymal and mesenchymal-toepithelial (MET) transitions, thus regulating cell identity and plasticity [92].

In addition, there are a large number of studies related to other signaling pathways involved in cancer progression, self-renewal, and metastasis of CSCs [56,93]. For example, recent developments to target and inhibit NF- $\mathrm{KB}$ in the ovarian cancer or disruption of the NF- $\mathrm{kB} / \mathrm{IL}-8$ signaling in breast cancer can potential targeted therapy for CSCs [94-96]. Signaling regulation can be complex in different types of tumors, with cross-interaction of pathways participating in the regulation of CSCs [54,97].

\subsection{Wnt Signaling}

The activation of the Wnt pathway is common in cancer and can be caused by mutations in Wnt signaling components [98-100], as well as in downstream targets. Indeed, 
aberrant activation of Wnt mediators such as APC, $\beta$-catenin, Axin, Wnt1, and others are found in many cancers. For instance, thyroid receptor-interacting protein 6 (TRIP6) is an adapter protein that belongs to Lim proteins Zixin family and plays an important role in regulating the function of CSCs in breast cancer through regulation of Wnt/ $\beta$-Catenin signaling [101]. Similarly, B-cell lymphoma/leukemia 11A (BCL11A) contributes to formation and invasion of tumor cells, stem cell self-renewal and activation of signalling by Wnt/ $\beta$-Catenin and the EMT pathway. In addition, BCL11A is associated with lung metastasis and increase stemness of breast cancer cells [102].

Interestingly, glioblastoma cells expressing high levels of Wnt demonstrated expression of OCT-4, SOX2, NANOG, NESTIN, and CD133, thus suggesting a role of Wnt signaling in the maintenance of glioma CSCs [103].

\subsection{Notch Signaling}

The Notch pathway is also important for CSC function, and it is activated in tumors surviving and adapting to their microenvironment. Activation of the Notch pathway contributes to self-renewal, metastasis, and suppression of apoptosis. For example, the aberrant transmission of Notch signals (Notch1 and Notch4) contributes to self-renewal and metastasis of breast CSCs [104]. High levels of Notch1, Notch3, JAG1, JAG2, and the target HES- 1 are found in pancreatic and breast cancers $[105,106]$. Notch signaling is activated under hypoxic conditions in breast cancer mediating chemoresistance and CSC expansion, which can be reversed by treatment with Notch inhibitors [107]. In addition, suppression of Notch1 via miR-34a can lead to an increase in breast cancer cell chemosensitivity to paclitaxel with a reduction in CSC proliferation and expression of the stemness marker ALDH1 [108]. Glioma stem cells are also regulated by activation of Notch1 and they show increased expression of the CSC genes OCT4 and CD133 under hypoxia [109].

\subsection{Hedgehog Signaling}

Together with Wnt and Notch signaling, the Hedgehog pathway is involved in embryonic development and organogenesis, including the nervous system, and organs such as lung, heart, and bowel [110]. Abnormal activation of the Hedgehog signaling pathway can be detected in CSCs [111,112]. For instance, it contributes to self-renewal, proliferation, and tumorigenicity of lung adenocarcinoma stem cells [113]. Through activation of the PTCH1 receptor and downstream effector Gli-1, Hedgehog signaling stimulates the transcription of the target genes OCT4, SOX2, NANOG, and C-MYC [114]. Zhu et al. showed that SHH, PTCH1, and Gli-1 are activated by TSPAN8 expression in breast CSCs leading to increased expression of NANOG, OCT4, and ALDHA1 genes, as well as increased stem cell selfrenewal and cell survival after treatment with adriamycin and paclitaxel [115]. Similarly, Hedgehog signaling stimulates self-renewal of glioma CSCs as they overexpress $\mathrm{SHH}$, PTCH11, and GLI1 [116]. The Hedgehog pathway has also been shown to be important for pancreatic CSCs, as inhibition of the ligand SHH by inhibition of sialidase-2 (Neu2) and desialylation leads to a decrease in stemness [117].

\subsection{JAK/STAT Signaling}

The JAK/STAT pathway promotes survival, self-renewal, hematopoiesis, and neurogenesis of ESCs [118]. This pathway is also activated in CSCs [119]. Among the different subtypes of STAT proteins, activation of STAT3 plays an important role in CSC function by regulating oncogenic signaling pathways. STAT3 is constitutively activated in many different cancers, including pancreatic breast, prostate, ovarian liver, colorectal, and bone cancers, as well as leukemia and melanoma. In addition, STAT3 activation is associated with the generation of glioblastoma stem cells and the metastatic potential of colon CSCs [90]. As well as STAT3, it has been shown that suppression of STAT1 reduces the formation of lung A549 tumor spheres which was maintained by the suppression of factors associated with stemness, such as SOX2, OCT4, and NANOG [120]. 


\subsection{AKT/mTOR Signaling}

The PI3K/AKT/mTOR signaling pathway is important for cell proliferation and survival, and abnormal activation of PI3K/mTOR signals is commonly found in cancer $[121,122]$. The activation of this pathway also increases the migration, invasion, and resistance of the CSCs [123]. The transmission of PI3K/AKT signals is part of the main molecular stemness program both in mouse and human pluripotent stem cells. The oncogenic version of PIK3CA ${ }^{\mathrm{H} 1047 \mathrm{R}}$ in cancer causes constitutive activation of the PI3K pathway and is associated with increased stemness in a dose-dependent manner, as shown in mouse models of breast, lung, and colorectal cancers [124]. Activation of the PI3KCA is also associated with induction of EMT and stem cell plasticity through multiple signals, including TGF $\beta$ [49].

\section{Influence of the Microenvironment on CSC}

Stem cells cannot survive outside their niche environment or in the absence of specific pluripotency factors and signaling pathways that support stem cell function [125]. Importantly, these factors can facilitate the emergence of stem cells from more differentiated cells, as these retain the ability to dedifferentiate and return to a more primitive developmental state [126].

The plasticity demonstrated by cancer cells is key in cancer as extrinsic factors can promote the acquisition of stemness by reprogramming cancer cells into CSCs. These factors include cytokine and growth factors secreted cells of the TME (mesenchymal stem cells (MSCs), macrophages, tumor-associated fibroblasts (TAFs)), as well as extracellular vesicles (EVs), and hypoxia [127]. In epithelial tissues, the activation of EMT has been linked to the formation of both normal cells and CSCs [128]. Fundamental to the process of gastrulation during embryo development, EMT is activated in the adult during wound healing and in cancer [129].

EMT is a reversible process with cells changing phenotypes from epithelial to mesenchymal and then back to epithelial through MET. These highly dynamic processes are regulated by paracrine signaling, most notably TGF- $\beta$, Wnt, and others involved in maintaining stem cell function, as described above. These pathways then induce expression of factors triggering EMT, including transcription factors of the TWIST, SNAIL, and ZEB families, splicing factors and microRNAs (e.g., miR34, miR200) which drive the loss of expression of adhesion molecules such as E-cadherin (encoded by the CDH1 gene), as well as the acquisition of mesenchymal markers, such as Vimentin [130].

Phenotypic plasticity linked to EMT has important implications for CSCs and their cellular origin in different tumor types. For instance, both epithelial and mesenchymal cells in the human breast can adopt a CSC phenotype and co-exist in tumor. Indeed, epithelial CSCs are proliferative and express ALDH, whereas mesenchymal CSCs are mostly quiescent and display a CD44hi/CD24- profile [131]. This dynamic equilibrium is regulated by the TME and the resulting heterogeneity is at the basis of the existence of different disease molecular and pathological subtypes in most solid tumors [42].

Factors associated with inflammation, such as tumor necrosis factor (TNF), interleukin6 (IL-6), and IL-1 $\beta$, can activate EMT [132]. For instance, IL-6 serum levels are high in osteosarcoma patients and the cytokine stimulates osteosarcoma stemness as measured in a self-renewal spheroid assay [133]. It was also found that IL-1 $\beta$ can increase the formation of colon cancer spheres, which show an up-regulation of stemness factor genes and increased drug resistance [134]. Finally, tumor necrosis factor (TNF)- $\alpha$ promotes HPV-associated oral carcinogenesis by increasing stemness [135].

These signaling pathways are also involved in the communication between cancerassociated fibroblasts (CAFs) present in the tissue stroma and cancer cells. Indeed, CAFs can activate signaling promoting cancer stemness through activation of Wnt and Notch signaling. CSCs, in turn, can influence CAFs through activation of signals involved in cancer progression, including the Hedgehog pathway [136]. Inter-related signaling pathways also link hypoxia with EMT. Indeed, hypoxia can directly induce EMT via the activation of 
the hypoxia-inducible factor (HIF)- $1 \alpha$ through cross-talk with TGF $\beta$ and Wnt $/ \beta$ catenin pathways. In addition, hypoxia can also induce EMT via HIF-independent pathways which include AMPK, PIK/AKT, MAPK, NF-kB, and Notch signalling [137].

Other non-cellular components of the TME can modulate CSCs, including ECM and EVs. Among ECM molecules, tenascin-C is involved in the stimulation of self-renewal of CSCs. In breast cancer, it promotes stemness through upregulation of the CSC marker LRG5 [138] and it is also associated with poor prognosis in glioblastoma and represents a candidate CSC markers in this cancer type [139]. In addition, the ECM provides a physical barrier to CSCs from cytotoxic drugs and may promote EMT, self-renewal, expression of CSC markers, and drug resistance. ECM properties such as stiffness and porosity affect various CSC functions. The rigidity of the ECM is involved in the regulation of selfrenewal and differentiation of stem cells $[140,141]$. Tumor ECM is usually more rigid than normal tissue ECM due to overexpression of collagens, proteoglycans, and ECM-modifying enzymes (lysyl oxidases) [142].

Finally, EVs isolated from tumor and stromal cells are involved in various stages of tumor progression such as proliferation, angiogenesis, metastasis, and drug resistance [143]. Tumor cells secrete a heterogeneous set of EVs, which differ in size, biogenesis, and molecular composition, which include cytoplasmic proteins, proteins interacting with lipid rafts, DNA, and RNA [144]. Communication through EVs is important for the maintenance of CSCs. For instance, Evs released by glioblastoma stem cells promote self-renewal and angiogenesis through endothelial tube formation [145]. Similarly, exosomes derived from TAFs promote the formation of colorectal cancer spheres by activating Wnt signaling and ultimately increasing the number of CSCs [146]. Gonzalez et al. also showed that stem/progenitor-enriched mammospheres from primary mammary epithelial cells can secrete extracellular vesicles that are capable of altering the expression levels of genes involved in EMT and stem cell markers [147].

\section{Models of Cancer Stemness and TME Interaction}

Culture models that allow cancer cells to re-acquire or enrich for stem cell characteristics have been developed to study CSCs. These culture models are aimed at preserving the biological characteristics of primary tumors, thus exhibiting the original tumor architecture and metabolic activity [148]. They also provide more accurate data on the effects of therapeutic agents and processes such as EMT and MET [149].

Among the 3D culture model systems which allow CSC self-renewal are spheroids and organoids cultured in suspension, scaffolds, matrix, and hydrogel cultures.

\subsection{Spheroids}

Spheroids are 3D tumor models that can be obtained by aggregation or spontaneous self-assembly of cancer cells. Aggregation can be caused by forced cell-to-cell contact by various methods such as hanging drop, liquid application/cell suspension culture, microwell culture (96-well round bottom plates), or microfluidics (i.e., gel encapsulation) [150]. Tumorsphere cultures are mainly generated by single cancer cell suspension in serum-free media. Under these conditions, only cells with self-renewal characteristics allow the formation of cell aggregates or spheroids that can proliferate and be serially passaged [151,152]. Spheroid cultures have been established from many different cancer types, including breast, prostate, bone, skin, brain, and colon tumors. Biomaterials can be used to support 3D CSC models, as they provide a physical structure to create a niche environment which is important to better sustain CSC function. Porous scaffolds are most commonly made of synthetic (polyglycolic and polylactic acids) or natural (collagen, alginate) polymers and hyaluronic acid. These have been used to support CSC proliferation in prostate and breast cancer, hepatocellular carcinoma, and glioblastoma. Hydrogels (natural and synthetic) are also widely used for 3D models of CSCs and they can be coupled with the use of extracellular matrix [153]. 


\subsection{Organoids}

Differently from spheroids, organoids are 3D cultures of stem cells that enable the differentiation and self-organization of tissue-like structures in vitro. These cultures are supported by embedding of cells in matrix and growth factors that normally support the survival and growth or stem cells in their natural niche. Organoids can be derived from cells isolated from primary tumors and many studies have demonstrated their ability to maintain tumor heterogeneity and pathological characteristics, even after multiple passaging. Organoids have been already established from a range of tumors, including colon, breast, pancreatic, liver, and prostate cancer. For example, 3D epithelial organoids can be established clonally from LRG5-positive intestinal stem cells and colon cancer cells [154].

Another application of organoids in CSC research is the use of iPSC technology and gene editing. Indeed, organoids can be generated through differentiation of gene-edited normal iPSC to carrying cancer driver mutations as well as iPSC derived from tumor cells isolated from cancer patients. The cancer iPSC-derived organoids have been shown to contain CSC that establish heterogeneous tumoroid structures that recapitulate primary tumors [155].

\subsection{TME Interaction}

Although the described models are powerful tools to maintain and enrich CSCs ex vivo, they face the challenge of mimicking the intra-tumor heterogeneity of primary tumors due to the modulation of CSC by their microenvironment. The bidirectional crosstalk between CSC and TME maintains cancer stemness. Niche cells of the TME communicate with CSC inducing self-renewal and tumor progression. Physical characteristics of the CSC niche, such as hypoxia and interaction with ECM, also affect CSC function [156]. These features can be modeled in vitro to some extent and current research efforts are directed to create model systems that closely resemble patient's cancer complexity. Histomorphological analysis shows that the spheroid model is divided into several zones, like a primary tumor. The outer marginal zone is characterized by preferentially proliferating cells, the middle zone by dormant cells, and the central part by a necrotic core due to lack of oxygen and nutrients. The central part of spheroids is characterized by the accumulation of lactate due to the significant consumption of glucose in the proliferating layer of cells whilst the distribution of glucose occurs evenly in all areas of spheroids [157]. Glycolytic metabolism and hypoxia are critical for maintaining stemness of CSCs. A hypoxic microenvironment can also activate CSC signalling. For instance, breast CSCs in mammospheres activate Wnt and Notch signalling in hypoxia [107]. This is mirrored by glioblastoma and colorectal CSC activating Notch, Hedgehog, and Wnt pathways [158]. ECM proteins play an important role in the modulation of stemness in CSC models. In a 3D model of colon cancer using afibrin gel, CSC properties were enriched with the activation of NANOG [133]. Similarly, collagen type I (Col-I) oligomer 3D matrices induce stemness and EMT in pancreatic cells [159].

Interactions with cells of the TME can be effectively modelled to study modulation of CSCs. Breast cancer cells can adopt a proliferative and EMT phenotype when cultured in 3D spheroids in the presence of mesenchymal stem cells (MSCs) [160]. The effect of MSCs on tumor cells has also been studied by creating hybrids with gastric cancer cells using polyethylene glycol (PEG) in vitro. These hybrids show a change in EMT with downregulation of E-cadherin and up-regulation of vimentin, $\mathrm{N}$-cadherin, $\alpha$-smooth muscle actin ( $\alpha$-SMA), and fibroblast activation protein (FAP). Hybrids increase the expression of the stemness factors OCT4, NANOG, SOX2, and LIN28, upregulate CD44 and CD133 as well as promote gastric xenograft tumor growth in vivo [161].

Therefore, the co-culture of cancer cell in 3D with cells of the TME can model the complexity of patient's tumors which, combined with the use of microfluidic devises and $3 \mathrm{D}$ bioprinting, can be used to investigate many aspects of tumor stemness. 
As the eradication of CSCs is clinically important, the study of CSCs in a TME context can provide invaluable clues in the fight against cancer, such as the discovery of new biomarkers for early detection of cancer and effective therapies [162,163].

\section{Conclusions and Future Perspectives}

The survival rate of cancer patients has increased significantly over the past decades, thanks to the development of anticancer therapy which includes interdisciplinary care, improved chemotherapy drugs, and targeted biological agents. However, despite these advances, the problems of cancer relapse and treatment of advanced-stage tumors remains unresolved. Currently, there is no therapy that would effectively treat patients with advanced metastatic disease. The main factors that complicate the treatment of patients are cellular heterogeneity, as well as the structural and molecular complexity of the tumors. Intratumor heterogeneity arises from genetic mutations, interactions with the microenvironment, and the presence of tumor stem cells. Activation of signaling pathways that promote self-renewal and chemoresistance allow CSCs not only to successfully survive unfavorable conditions but also to self-renew with the production of resistant clones. Therefore, targeting cancer stemness is an increasingly important therapeutic approach to halt tumor progression, recurrence, and resistance to therapy.

To this end, there is some evidence that some compounds have a direct effect on CSCs. For instance, salinomycin, a potassium ionophore, can selectively kill breast cancer stem cells and induce epithelial differentiation of breast tumor cells, promoting effective tumor removal [164]. In addition, epigallocatechin gallate reduces the stem and oncogenicity of human lung cancer cells by inhibiting AXL receptors [165].

Although promising, data of effective CSC therapies are limited and therefore the development of CSC-specific therapies requires better knowledge of the relationship between CSCs and their microenvironment. A deeper understanding of the intrinsic and extrinsic factors involved in shaping this interaction is likely to be essential to overcome the barrier of CSC plasticity. Although therapeutic strategies aimed at inhibiting the signaling pathways of CSC are available (Table 2), it is necessary to continue researching new strategies that can target factors inducing cancer stemness, including TME (EMT, hypoxia, CAFs, vesicles), metabolism, and chemoresistance [166].

Table 2. Therapeutic agents targeting cancer stem cells.

\begin{tabular}{|c|c|c|c|}
\hline Agent & Notes & Clinical Trials & Reference \\
\hline $\begin{array}{c}\text { MRK-003, } \\
\text { MK-0752, R4733 }\end{array}$ & Notch inhibitors & $\begin{array}{l}\text { NCT00106145 } \\
\text { NCT01154452 }\end{array}$ & [167-169] \\
\hline $\begin{array}{l}\text { CAL-101, } \\
\text { XL-147 }\end{array}$ & PI3K inhibitors & $\begin{array}{l}\text { NCT01629615 } \\
\text { NCT01613950 } \\
\text { NCT00907205 }\end{array}$ & {$[170,171]$} \\
\hline $\begin{array}{l}\text { KRX-0401, } \\
\text { RX-0201 }\end{array}$ & AKT inhibitors & $\begin{array}{l}\text { NCT00590954 } \\
\text { NCT01028495 }\end{array}$ & [172-174] \\
\hline BMS-863923, IPI-926 & Hedgehog inhibitors & $\begin{array}{l}\text { NCT01546038 } \\
\text { NCT01130142 } \\
\text { NCT01700049 }\end{array}$ & [175] \\
\hline $\begin{array}{l}\text { OMP-54F28, PRI-724, } \\
\text { CWP232291 }\end{array}$ & Wnt inhibitors & $\begin{array}{l}\text { NCT01606579 } \\
\text { NCT01351103 } \\
\text { NCT02092363 }\end{array}$ & [176-178] \\
\hline $\begin{array}{l}\text { BBI503, } \\
\text { BBI608 }\end{array}$ & NANOG inhibitors & $\begin{array}{l}\text { NCT02232633 } \\
\text { NCT02315534 }\end{array}$ & {$[179,180]$} \\
\hline
\end{tabular}

However, a significant obstacle to the development of effective therapies that can take into account cancer complexity is the discrepancy between model systems and patient's tumors. Modelling of the TME is especially complex and therefore the use of clinically 
relevant and close to patient models can address the probe of the high attrition rate in cancer drug development. In addition, the combination of different models can add to their predictive value. For instance, the use of CSCs to create cultures of non-adherent spheres, three-dimensional tumor organoids, and patient-derived xenografts have shown that treatment with Wnt and Notch inhibitors can block the proliferation and self-renewal of CSCs [11].

Thus, the use of advanced and complex model systems will expand the possibilities of CSC therapy, which will stimulate the development of precision medicine.

Author Contributions: Conceptualization, A.P., Z.G., V.S. and A.R.; writing-original draft preparation, A.P., Z.G., C.A. and V.S.; writing-review and editing, V.S. and A.R.; supervision, V.S. and A.R. All authors have read and agreed to the published version of the manuscript.

Funding: This paper has been supported by the Russian Science Foundation grant 21-74-10021.

Acknowledgments: This paper has been supported by the Kazan Federal University Strategic Academic Leadership Program (PRIORITY-2030).

Conflicts of Interest: The authors declare no conflict of interest.

\section{References}

1. Feinberg, A.P.; Ohlsson, R.; Henikoff, S. The epigenetic progenitor origin of human cancer. Nat. Rev. Genet. 2006, 7, 21-33. [CrossRef] [PubMed]

2. Elkashty, O.A.; Hariharan, A.; Tran, S.D. Aging, stem cells and cancer updated. Aging 2021, 13, 20854-20855. [CrossRef] [PubMed]

3. Sell, S. On the Stem Cell Origin of Cancer. Am. J. Pathol. 2010, 176, 2584-2594. [CrossRef] [PubMed]

4. Beck, B.; Blanpain, C. Unravelling cancer stem cell potential. Nat. Rev. Cancer 2013, 13, 727-738. [CrossRef] [PubMed]

5. Albini, A.; Bruno, A.; Gallo, C.; Pajardi, G.; Noonan, D.M.; Dallaglio, K. Cancer stem cells and the tumor microenvironment: Interplay in tumor heterogeneity. Connect Tissue Res. 2015, 56, 414-425. [CrossRef]

6. Girouard, S.D.; Murphy, G.F. Melanoma stem cells: Not rare, but well done. Lab. Investig. 2011, 91, 647-664. [CrossRef]

7. Reya, T.; Morrison, S.J.; Clarke, M.F.; Weissman, I.L. Stem cells, cancer, and cancer stem cells. Nature 2001, 414, 105-111. [CrossRef]

8. Batlle, E.; Clevers, H. Cancer stem cells revisited. Nat. Med. 2017, 23, 1124-1134. [CrossRef]

9. Capp, J.P. Cancer Stem Cells: From Historical Roots to a New Perspective. J. Oncol. 2019, 2019, 5189232 . [CrossRef]

10. Kim, W.T.; Ryu, C.J. Cancer stem cell surface markers on normal stem cells. BMB Rep. 2017, 50, 285-298. [CrossRef]

11. Fendler, A.; Bauer, D.; Busch, J.; Jung, K.; Wulf-Goldenberg, A.; Kunz, S.; Song, K.; Myszczyszyn, A.; Elezkurtaj, S.; Erguen, B.; et al. Inhibiting WNT and NOTCH in renal cancer stem cells and the implications for human patients. Nat. Commun. 2020, 11,929. [CrossRef]

12. Dou, J.; Gu, N. Emerging strategies for the identification and targeting of cancer stem cells. Tumor Biol. 2010, 31, 243-253. [CrossRef]

13. Duan, J.J.; Qiu, W.; Xu, S.L.; Wang, B.; Ye, X.Z.; Ping, Y.F.; Zhang, X.; Bian, X.W.; Yu, S.C. Strategies for isolating and enriching cancer stem cells: Well begun is half done. Stem Cells Dev. 2013, 22, 2221-2239. [CrossRef] [PubMed]

14. Goossens, S.; Vandamme, N.; Van Vlierberghe, P.; Berx, G. EMT transcription factors in cancer development re-evaluated: Beyond EMT and MET. Biochim. Biophys. Acta Rev. Cancer 2017, 1868, 584-591. [CrossRef] [PubMed]

15. Mercurio, A.M. VEGF/Neuropilin Signaling in Cancer Stem Cells. Int. J. Mol. Sci. 2019, 20, 490. [CrossRef]

16. Pattabiraman, D.R.; Weinberg, R.A. Tackling the cancer stem cells-What challenges do they pose? Nat. Rev. Drug Discov. 2014, 13, 497-512. [CrossRef]

17. Farace, C.; Pisano, A.; Grinan-Lison, C.; Solinas, G.; Jimenez, G.; Serra, M.; Carrillo, E.; Scognamillo, F.; Attene, F.; Montella, A.; et al. Deregulation of cancer-stem-cell-associated miRNAs in tissues and sera of colorectal cancer patients. Oncotarget 2020, 11, 116-130. [CrossRef] [PubMed]

18. Nallanthighal, S.; Heiserman, J.P.; Cheon, D.J. The Role of the Extracellular Matrix in Cancer Stemness. Front. Cell Dev. Biol. 2019, 7, 86. [CrossRef] [PubMed]

19. Bonnet, D.; Dick, J.E. Human acute myeloid leukemia is organized as a hierarchy that originates from a primitive hematopoietic cell. Nat. Med. 1997, 3, 730-737. [CrossRef] [PubMed]

20. Jijiwa, M.; Demir, H.; Gupta, S.; Leung, C.; Joshi, K.; Orozco, N.; Huang, T.; Yildiz, V.O.; Shibahara, I.; de Jesus, J.A.; et al. CD44v6 Regulates Growth of Brain Tumor Stem Cells Partially through the AKT-Mediated Pathway. PLoS ONE 2011, 6, e24217. [CrossRef]

21. Matsui, W.; Huff, C.A.; Wang, Q.J.; Malehorn, M.T.; Barber, J.; Tanhehco, Y.; Smith, B.D.; Civin, C.I.; Jones, R.J. Characterization of clonogenic multiple myeloma cells. Blood 2004, 103, 2332-2336. [CrossRef] [PubMed]

22. Singh, S.K.; Hawkins, C.; Clarke, I.D.; Squire, J.A.; Bayani, J.; Hide, T.; Henkelman, R.M.; Cusimano, M.D.; Dirks, P.B. Identification of human brain tumour initiating cells. Nature 2004, 432, 396-401. [CrossRef] [PubMed] 
23. Zhang, S.; Balch, C.; Chan, M.W.; Lai, H.C.; Matei, D.; Schilder, J.M.; Yan, P.S.; Huang, T.H.M.; Nephew, K.P. Identification and characterization of ovarian cancer-initiating cells from primary human tumors. Cancer Res. 2008, 68, 4311-4320. [CrossRef] [PubMed]

24. Szotek, P.P.; Pieretti-Vanmarcke, R.; Masiakos, P.T.; Dinulescut, D.M.; Connolly, D.; Foster, R.; Dombkowski, D.; Preffer, F.; MacLaughlin, D.T.; Donahoe, P.K. Ovarian cancer side population defines cells with stem cell-like characteristics and Mullerian Inhibiting Substance responsiveness. Proc. Natl. Acad. Sci. USA 2006, 103, 11154-11159. [CrossRef]

25. Sims-Mourtada, J.; Izzo, J.G.; Ajani, J.; Chao, K.S.C. Sonic Hedgehog promotes multiple drug resistance by regulation of drug transport. Oncogene 2007, 26, 5674-5679. [CrossRef] [PubMed]

26. Collins, A.T.; Berry, P.A.; Hyde, C.; Stower, M.J.; Maitland, N.J. Prospective identification of tumorigenic prostate cancer stem cells. Cancer Res. 2005, 65, 10946-10951. [CrossRef] [PubMed]

27. Vermeulen, L.; Melo, F.; van der Heijden, M.; Cameron, K.; de Jong, J.H.; Borovski, T.; Tuynman, J.B.; Todaro, M.; Merz, C.; Rodermond, H.; et al. Wnt activity defines colon cancer stem cells and is regulated by the microenvironment. Nat. Cell Biol. 2010, 12, 468-476. [CrossRef]

28. Katoh, Y.; Katoh, M. Comparative genomics on PROM1 gene encoding stem cell marker CD133. Int. J. Mol. Med. 2007, 19, 967-970. [CrossRef]

29. Van Der Flier, L.G.; Sabates-Bellver, J.; Oving, I.; Haegebarth, A.; De Palo, M.; Anti, M.; Van Gijn, M.E.; Suijkerbuijk, S.; Van De Wetering, M.; Marra, G.; et al. The intestinal Wnt/TCF signature. Gastroenterology 2007, 132, 628-632. [CrossRef]

30. Dalerba, P.; Dylla, S.J.; Park, I.K.; Liu, R.; Wang, X.H.; Cho, R.W.; Hoey, T.; Gurney, A.; Huang, E.H.; Simeone, D.M.; et al Phenotypic characterization of human colorectal cancer stem cells. Proc. Natl. Acad. Sci. USA 2007, 104, 10158-10163. [CrossRef]

31. Lonardo, E.; Hermann, P.C.; Mueller, M.T.; Huber, S.; Balic, A.; Miranda-Lorenzo, I.; Zagorac, S.; Alcala, S.; Roderiguez-Arabaolaza, I.; Ramirez, J.C.; et al. Nodal/Activin Signaling Drives Self-Renewal and Tumorigenicity of Pancreatic Cancer Stem Cells and Provides a Target for Combined Drug Therapy. Cell Stem Cell 2011, 9, 433-446. [CrossRef] [PubMed]

32. Li, C.W.; Lee, C.J.; Simeone, D.M. Identification of Human Pancreatic Cancer Stem Cells. In Cancer Stem Cells: Methods Protoc; Yu, J.S., Ed.; Methods in Molecular Biology; Humana Press Inc.: Totowa, NJ, USA, 2009; Volume 568, pp. 161-173.

33. Yang, Z.F.; Ho, D.W.; Ng, M.N.; Lau, C.K.; Yu, W.C.; Ngai, P.; Chu, P.W.K.; Lam, C.T.; Poon, R.T.P.; Fan, S.T. Significance of CD90(+) cancer stem cells in human liver cancer. Cancer Cell 2008, 13, 153-166. [CrossRef] [PubMed]

34. Eramo, A.; Lotti, F.; Sette, G.; Pilozzi, E.; Biffoni, M.; Di Virgilio, A.; Conticello, C.; Ruco, L.; Peschle, C.; De Maria, R. Identification and expansion of the tumorigenic lung cancer stem cell population. Cell Death Differ. 2008, 15, 504-514. [CrossRef] [PubMed]

35. Mei, Y.; Cai, D.Y.; Dai, X.F. Modulating cancer stemness provides luminal a breast cancer cells with HER2 positive-like features. J. Cancer 2020, 11, 1162-1169. [CrossRef]

36. Liu, S.L.; Dontu, G.; Mantle, I.D.; Patel, S.; Ahn, N.S.; Jackson, K.W.; Suri, P.; Wicha, M.S. Hedgehog signaling and Bmi-1 regulate self-renewal of normal and malignant human mammary stem cells. Cancer Res. 2006, 66, 6063-6071. [CrossRef]

37. Liu, S.L.; Ginestier, C.; Ou, S.J.; Clouthier, S.G.; Patel, S.H.; Monville, F.; Korkaya, H.; Heath, A.; Dutcher, J.; Kleer, C.G.; et al. Breast Cancer Stem Cells Are Regulated by Mesenchymal Stem Cells through Cytokine Networks. Cancer Res. 2011, 71, 614-624. [CrossRef]

38. Bocci, F.; Gearhart-Serna, L.; Boareto, M.; Ribeiro, M.; Ben-Jacob, E.; Devi, G.R.; Levine, H.; Onuchic, J.N.; Jolly, M.K. Toward understanding cancer stem cell heterogeneity in the tumor microenvironment. Proc. Natl. Acad. Sci. USA 2019, 116, 148-157. [CrossRef]

39. Plaks, V.; Kong, N.; Werb, Z. The cancer stem cell niche: How essential is the niche in regulating stemness of tumor cells? Cell Stem Cell 2015, 16, 225-238. [CrossRef]

40. Viatour, P. Bridges between Cell Cycle Regulation and Self-Renewal Maintenance. Genes Cancer 2012, 3, 670-677. [CrossRef]

41. Simons, B.D.; Clevers, H. Strategies for homeostatic stem cell self-renewal in adult tissues. Cell 2011, 145, 851-862. [CrossRef]

42. Brooks, M.D.; Burness, M.L.; Wicha, M.S. Therapeutic Implications of Cellular Heterogeneity and Plasticity in Breast Cancer. Cell Stem Cell 2015, 17, 260-271. [CrossRef]

43. Cabrera, M.C.; Hollingsworth, R.E.; Hurt, E.M. Cancer stem cell plasticity and tumor hierarchy. World J. Stem Cells 2015, 7, 27-36. [CrossRef]

44. Chaffer, C.L.; Brueckmann, I.; Scheel, C.; Kaestli, A.J.; Wiggins, P.A.; Rodrigues, L.O.; Brooks, M.; Reinhardt, F.; Su, Y.; Polyak, K.; et al. Normal and neoplastic nonstem cells can spontaneously convert to a stem-like state. Proc. Natl. Acad. Sci. USA 2011, 108, 7950-7955. [CrossRef]

45. Borovski, T.; Melo, F.D.E.; Vermeulen, L.; Medema, J.P. Cancer Stem Cell Niche: The Place to Be. Cancer Res. 2011, 71, 634-639. [CrossRef]

46. Jing, Y.; Han, Z.; Zhang, S.; Liu, Y.; Wei, L. Epithelial-Mesenchymal Transition in tumor microenvironment. Cell Biosci. 2011, 1, 29. [CrossRef]

47. Mittal, V. Epithelial Mesenchymal Transition in Tumor Metastasis. Annu. Rev. Pathol. 2018, 13, 395-412. [CrossRef]

48. Abell, A.N.; Johnson, G.L. Implications of Mesenchymal Cells in Cancer Stem Cell Populations: Relevance to EMT. Curr. Pathobiol. Rep. 2014, 2, 21-26. [CrossRef]

49. Shibue, T.; Weinberg, R.A. EMT, CSCs, and drug resistance: The mechanistic link and clinical implications. Nat. Rev. Clin. Oncol. 2017, 14, 611-629. [CrossRef] 
50. Mego, M.; Reuben, J.; Mani, S. Epithelial-Mesenchymal Transition (EMT) and Cancer Stem Cells (CSCs): The Traveling Metastasis; Cancer Drug Discovery and Development; Humana Press: Totowa, NJ, USA, 2017; p. 14.

51. Tanabe, S.; Quader, S.; Cabral, H.; Ono, R. Interplay of EMT and CSC in Cancer and the Potential Therapeutic Strategies. Front. Pharm. 2020, 11, 904. [CrossRef]

52. Aponte, P.M.; Caicedo, A. Stemness in Cancer: Stem Cells, Cancer Stem Cells, and Their Microenvironment. Stem Cells Int. 2017, 2017, 5619472. [CrossRef]

53. Lin, D.; Shen, L.; Luo, M.; Zhang, K.; Li, J.; Yang, Q.; Zhu, F.; Zhou, D.; Zheng, S.; Chen, Y.; et al. Circulating tumor cells: Biology and clinical significance. Signal Transduct Target 2021, 6, 404. [CrossRef]

54. Visvader, J.E.; Lindeman, G.J. Cancer stem cells: Current status and evolving complexities. Cell Stem Cell 2012, 10, 717-728. [CrossRef]

55. Laplane, L.; Solary, E. Towards a classification of stem cells. Elife 2019, 8, e46563. [CrossRef]

56. Yang, L.; Shi, P.; Zhao, G.; Xu, J.; Peng, W.; Zhang, J.; Zhang, G.; Wang, X.; Dong, Z.; Chen, F.; et al. Targeting cancer stem cell pathways for cancer therapy. Signal Transduct Target 2020, 5, 8. [CrossRef]

57. Muller, M.; Hermann, P.C.; Liebau, S.; Weidgang, C.; Seufferlein, T.; Kleger, A.; Perkhofer, L. The role of pluripotency factors to drive stemness in gastrointestinal cancer. Stem Cell Res. 2016, 16, 349-357. [CrossRef]

58. Zhu, Y.; Huang, S.; Chen, S.; Chen, J.; Wang, Z.; Wang, Y.; Zheng, H. SOX2 promotes chemoresistance, cancer stem cells properties, and epithelial-mesenchymal transition by beta-catenin and Beclin1/autophagy signaling in colorectal cancer. Cell Death Dis. 2021, 12, 449. [CrossRef]

59. Yasumizu, Y.; Rajabi, H.; Jin, C.; Hata, T.; Pitroda, S.; Long, M.D.; Hagiwara, M.; Li, W.; Hu, Q.; Liu, S.; et al. MUC1-C regulates lineage plasticity driving progression to neuroendocrine prostate cancer. Nat. Commun. 2020, 11, 338. [CrossRef]

60. Hepburn, A.C.; Steele, R.E.; Veeratterapillay, R.; Wilson, L.; Kounatidou, E.E.; Barnard, A.; Berry, P.; Cassidy, J.R.; Moad, M.; El-Sherif, A.; et al. The induction of core pluripotency master regulators in cancers defines poor clinical outcomes and treatment resistance. Oncogene 2019, 38, 4412-4424. [CrossRef]

61. Huang, J.; Zhang, L.; Wan, D.; Zhou, L.; Zheng, S.; Lin, S.; Qiao, Y. Extracellular matrix and its therapeutic potential for cancer treatment. Signal Transduct Target 2021, 6, 153. [CrossRef]

62. Wang, D.; Lu, P.; Zhang, H.; Luo, M.; Zhang, X.; Wei, X.; Gao, J.; Zhao, Z.; Liu, C. Oct-4 and Nanog promote the epithelialmesenchymal transition of breast cancer stem cells and are associated with poor prognosis in breast cancer patients. Oncotarget 2014, 5, 10803-10815. [CrossRef]

63. Ohnishi, K.; Semi, K.; Yamamoto, T.; Shimizu, M.; Tanaka, A.; Mitsunaga, K.; Okita, K.; Osafune, K.; Arioka, Y.; Maeda, T.; et al. Premature Termination of Reprogramming In Vivo Leads to Cancer Development through Altered Epigenetic Regulation. Cell 2014, 156, 663-677. [CrossRef]

64. Hochedlinger, K.; Yamada, Y.; Beard, C.; Jaenisch, R. Ectopic expression of Oct-4 blocks progenitor-cell differentiation and causes dysplasia in epithelial tissues. Cell 2005, 121, 465-477. [CrossRef]

65. Murakami, S.; Ninomiya, W.; Sakamoto, E.; Shibata, T.; Akiyama, H.; Tashiro, F. SRY and OCT4 Are Required for the Acquisition of Cancer Stem Cell-Like Properties and Are Potential Differentiation Therapy Targets. Stem Cells 2015, 33, 2652-2663. [CrossRef]

66. Du, Z.; Jia, D.; Liu, S.; Wang, F.; Li, G.; Zhang, Y.; Cao, X.; Ling, E.A.; Hao, A. Oct4 is expressed in human gliomas and promotes colony formation in glioma cells. Glia 2009, 57, 724-733. [CrossRef]

67. Wang, X.Q.; Ongkeko, W.M.; Chen, L.; Yang, Z.F.; Lu, P.; Chen, K.K.; Lopez, J.P.; Poon, R.T.P.; Fan, S.T. Octamer 4 (Oct4) Mediates Chemotherapeutic Drug Resistance in Liver Cancer Cells Through a Potential Oct4-AKT-ATP-Binding Cassette G2 Pathway. Hepatology 2010, 52, 528-539. [CrossRef]

68. Fujino, S.; Miyoshi, N. Oct4 Gene Expression in Primary Colorectal Cancer Promotes Liver Metastasis. Stem Cells Int. 2019, 2019, 7896524. [CrossRef]

69. Lu, C.S.; Shiau, A.L.; Su, B.H.; Hsu, T.S.; Wang, C.T.; Su, Y.C.; Tsai, M.S.; Feng, Y.H.; Tseng, Y.L.; Yen, Y.T.; et al. Oct4 promotes M2 macrophage polarization through upregulation of macrophage colony-stimulating factor in lung cancer. J. Hematol. Oncol. 2020, 13, 62. [CrossRef]

70. Hagey, D.W.; Klum, S.; Kurtsdotter, I.; Zaouter, C.; Topcic, D.; Andersson, O.; Bergsland, M.; Muhr, J. SOX2 regulates common and specific stem cell features in the CNS and endoderm derived organs. PLoS Genet. 2018, 14, e1007224. [CrossRef]

71. Schaefer, T.; Lengerke, C. SOX2 protein biochemistry in stemness, reprogramming, and cancer: The PI3K/AKT/SOX2 axis and beyond. Oncogene 2020, 39, 278-292. [CrossRef]

72. Liu, P.; Tang, H.; Song, C.; Wang, J.; Chen, B.; Huang, X.; Pei, X.; Liu, L. SOX2 Promotes Cell Proliferation and Metastasis in Triple Negative Breast Cancer. Front. Pharm. 2018, 9, 942. [CrossRef]

73. Maurizi, G.; Verma, N.; Gadi, A.; Mansukhani, A.; Basilico, C. Sox2 is required for tumor development and cancer cell proliferation in osteosarcoma. Oncogene 2018, 37, 4626-4632. [CrossRef] [PubMed]

74. Han, S.; Huang, T.; Wu, X.; Wang, X.; Liu, S.; Yang, W.; Shi, Q.; Li, H.; Hou, F. Prognostic Value of CD133 and SOX2 in Advanced Cancer. J. Oncol. 2019, 2019, 3905817. [CrossRef] [PubMed]

75. Heurtier, V.; Owens, N.; Gonzalez, I.; Mueller, F.; Proux, C.; Mornico, D.; Clerc, P.; Dubois, A.; Navarro, P. The molecular logic of Nanog-induced self-renewal in mouse embryonic stem cells. Nat. Commun. 2019, 10, 1109. [CrossRef] 
76. Chiou, S.H.; Wang, M.L.; Chou, Y.T.; Chen, C.J.; Hong, C.F.; Hsieh, W.J.; Chang, H.T.; Chen, Y.S.; Lin, T.W.; Hsu, H.S.; et al. Coexpression of Oct4 and Nanog enhances malignancy in lung adenocarcinoma by inducing cancer stem cell-like properties and epithelial-mesenchymal transdifferentiation. Cancer Res. 2010, 70, 10433-10444. [CrossRef]

77. Lin, T.; Ding, Y.Q.; Li, J.M. Overexpression of Nanog protein is associated with poor prognosis in gastric adenocarcinoma. Med. Oncol. 2012, 29, 878-885. [CrossRef]

78. Chiou, S.H.; Yu, C.C.; Huang, C.Y.; Lin, S.C.; Liu, C.J.; Tsai, T.H.; Chou, S.H.; Chien, C.S.; Ku, H.H.; Lo, J.F. Positive correlations of Oct-4 and Nanog in oral cancer stem-like cells and high-grade oral squamous cell carcinoma. Clin. Cancer Res. 2008, 14, 4085-4095. [CrossRef]

79. de Vicente, J.C.; Rodriguez-Santamarta, T.; Rodrigo, J.P.; Allonca, E.; Vallina, A.; Singhania, A.; Donate-Perez Del Molino, P.; Garcia-Pedrero, J.M. The Emerging Role of NANOG as an Early Cancer Risk Biomarker in Patients with Oral Potentially Malignant Disorders. J. Clin. Med. 2019, 8, 1376. [CrossRef]

80. Wang, X.; Jin, J.; Wan, F.; Zhao, L.; Chu, H.; Chen, C.; Liao, G.; Liu, J.; Yu, Y.; Teng, H.; et al. AMPK Promotes SPOP-Mediated NANOG Degradation to Regulate Prostate Cancer Cell Stemness. Dev. Cell 2019, 48, 345-360.e7. [CrossRef]

81. Dehghan Harati, M.; Rodemann, H.P.; Toulany, M. Nanog Signaling Mediates Radioresistance in ALDH-Positive Breast Cancer Cells. Int J Mol Sci 2019, 20, 1151. [CrossRef]

82. Ghaleb, A.M.; Yang, V.W. Kruppel-like factor 4 (KLF4): What we currently know. Gene 2017, 611, 27-37. [CrossRef]

83. Hsieh, M.H.; Chen, Y.T.; Chen, Y.T.; Lee, Y.H.; Lu, J.; Chien, C.L.; Chen, H.F.; Ho, H.N.; Yu, C.J.; Wang, Z.Q.; et al. PARP1 controls KLF4-mediated telomerase expression in stem cells and cancer cells. Nucleic Acids Res. 2017, 45, 10492-10503. [CrossRef] [PubMed]

84. Riverso, M.; Montagnani, V.; Stecca, B. KLF4 is regulated by RAS/RAF/MEK/ERK signaling through E2F1 and promotes melanoma cell growth. Oncogene 2017, 36, 3322-3333. [CrossRef]

85. Qi, X.T.; Li, Y.L.; Zhang, Y.Q.; Xu, T.; Lu, B.; Fang, L.; Gao, J.Q.; Yu, L.S.; Zhu, D.F.; Yang, B.; et al. KLF4 functions as an oncogene in promoting cancer stem cell-like characteristics in osteosarcoma cells. Acta Pharm. Sin. 2019, 40, 546-555. [CrossRef] [PubMed]

86. Ding, X.; Zhong, T.; Jiang, L.; Huang, J.; Xia, Y.; Hu, R. miR-25 enhances cell migration and invasion in non-small-cell lung cancer cells via ERK signaling pathway by inhibiting KLF4. Mol. Med. Rep. 2018, 17, 7005-7016. [CrossRef] [PubMed]

87. Wang, B.; Shen, A.; Ouyang, X.; Zhao, G.; Du, Z.; Huo, W.; Zhang, T.; Wang, Y.; Yang, C.; Dong, P.; et al. KLF4 expression enhances the efficacy of chemotherapy drugs in ovarian cancer cells. Biochem. Biophys. Res. Commun. 2017, 484, 486-492. [CrossRef] [PubMed]

88. Dang, C.V. MYC on the path to cancer. Cell 2012, 149, 22-35. [CrossRef]

89. Beroukhim, R.; Mermel, C.H.; Porter, D.; Wei, G.; Raychaudhuri, S.; Donovan, J.; Barretina, J.; Boehm, J.S.; Dobson, J.; Urashima, M.; et al. The landscape of somatic copy-number alteration across human cancers. Nature 2010, 463, 899-905. [CrossRef]

90. Yoshida, G.J. Emerging roles of Myc in stem cell biology and novel tumor therapies. J. Exp. Clin. Cancer Res. 2018, $37,1-20$.

91. Galardi, S.; Savino, M.; Scagnoli, F.; Pellegatta, S.; Pisati, F.; Zambelli, F.; Illi, B.; Annibali, D.; Beji, S.; Orecchini, E.; et al. Resetting cancer stem cell regulatory nodes upon MYC inhibition. EMBO Rep. 2016, 17, 1872-1889. [CrossRef]

92. Fabregat, I.; Malfettone, A.; Soukupova, J. New Insights into the Crossroads between EMT and Stemness in the Context of Cancer. J. Clin. Med. 2016, 5, 37. [CrossRef]

93. Sever, R.; Brugge, J.S. Signal transduction in cancer. Cold Spring Harb. Perspect. Med. 2015, 5, a006098. [CrossRef]

94. Harrington, B.S.; Annunziata, C.M. NF-kappaB Signaling in Ovarian Cancer. Cancers 2019, 11, 1182. [CrossRef] [PubMed]

95. Choi, H.S.; Kim, J.H.; Kim, S.L.; Lee, D.S. Disruption of the NF-kappaB/IL-8 Signaling Axis by Sulconazole Inhibits Human Breast Cancer Stem Cell Formation. Cells 2019, 8, 1007. [CrossRef] [PubMed]

96. Rinkenbaugh, A.L.; Baldwin, A.S. The NF-kappaB Pathway and Cancer Stem Cells. Cells 2016, 5, 16. [CrossRef] [PubMed]

97. Katoh, M. Networking of WNT, FGF, Notch, BMP, and Hedgehog signaling pathways during carcinogenesis. Stem Cell Rev. 2007, 3, 30-38. [CrossRef] [PubMed]

98. Clements, W.M.; Wang, J.; Sarnaik, A.; Kim, O.J.; MacDonald, J.; Fenoglio-Preiser, C.; Groden, J.; Lowy, A.M. beta-Catenin mutation is a frequent cause of Wnt pathway activation in gastric cancer. Cancer Res 2002, 62, 3503-3506.

99. Abd El-Rehim, D.; Ali, M.M. Aberrant expression of beta-catenin in invasive ductal breast carcinomas. J. Egypt Natl. Canc. Inst. 2009, 21, 185-195.

100. Kudo, J.; Nishiwaki, T.; Haruki, N.; Ishiguro, H.; Shibata, Y.; Terashita, Y.; Sugiura, H.; Shinoda, N.; Kimura, M.; Kuwabara, Y.; et al. Aberrant nuclear localization of beta-catenin without genetic alterations in beta-catenin or Axin genes in esophageal cancer. World J. Surg. Oncol. 2007, 5, 21. [CrossRef]

101. Zhao, X.; Jiang, C.; Xu, R.; Liu, Q.; Liu, G.; Zhang, Y. TRIP6 enhances stemness property of breast cancer cells through activation of Wnt/beta-catenin. Cancer Cell Int. 2020, 20, 51. [CrossRef]

102. Zhu, L.; Pan, R.; Zhou, D.; Ye, G.; Tan, W. BCL11A enhances stemness and promotes progression by activating Wnt/beta-catenin signaling in breast cancer. Cancer Manag. Res. 2019, 11, 2997-3007. [CrossRef]

103. Liu, S.; Pong, U.K.; Zhang, J.T.; Tsang, L.L.; Huang, J.W.; Tu, S.P.; Jiang, X.H. R-spodin2 enhances canonical Wnt signaling to maintain the stemness of glioblastoma cells. Cancer Cell Int. 2018, 18, 156. [CrossRef] [PubMed]

104. Stylianou, S.; Clarke, R.B.; Brennan, K. Aberrant activation of notch signaling in human breast cancer. Cancer Res. 2006, 66, 1517-1525. [CrossRef] [PubMed] 
105. Abel, E.V.; Kim, E.J.; Wu, J.J.; Hynes, M.; Bednar, F.; Proctor, E.; Wang, L.D.; Dziubinski, M.L.; Simeone, D.M. The Notch Pathway Is Important in Maintaining the Cancer Stem Cell Population in Pancreatic Cancer. PLoS ONE 2014, 9, e91983. [CrossRef] [PubMed]

106. Koury, J.; Zhong, L.; Hao, J.J. Targeting Signaling Pathways in Cancer Stem Cells for Cancer Treatment. Stem Cells Int. 2017, 2017, 2925869. [CrossRef]

107. Yan, Y.Y.; Liu, F.X.; Han, L.; Zhao, L.; Chen, J.J.; Olopade, O.I.; He, M.; Wei, M.J. HIF-2 alpha promotes conversion to a stem cell phenotype and induces chemoresistance in breast cancer cells by activating Wnt and Notch pathways. J. Exp. Clin. Cancer Res. 2018, 37, 256. [CrossRef]

108. Kang, L.; Mao, J.; Tao, Y.; Song, B.; Ma, W.; Lu, Y.; Zhao, L.; Li, J.; Yang, B.; Li, L. MicroRNA-34a suppresses the breast cancer stem cell-like characteristics by downregulating Notch1 pathway. Cancer Sci. 2015, 106, 700-708. [CrossRef]

109. Zeng, F.; Chen, H.; Zhang, Z.H.; Yao, T.; Wang, G.; Zeng, Q.X.; Duan, S.H.; Zhan, Y.Q. Regulating glioma stem cells by hypoxia through the Notch1 and Oct3/4 signaling pathway. Oncol. Lett. 2018, 16, 6315-6322. [CrossRef]

110. Petrova, R.; Joyner, A.L. Roles for Hedgehog signaling in adult organ homeostasis and repair. Development 2014, 141, 3445-3457. [CrossRef]

111. Amantini, C.; Morelli, M.B.; Nabissi, M.; Cardinali, C.; Santoni, M.; Gismondi, A.; Santoni, G. Capsaicin triggers autophagic cell survival which drives epithelial mesenchymal transition and chemoresistance in bladder cancer cells in an Hedgehog-dependent manner. Oncotarget 2016, 7, 50180-50194. [CrossRef]

112. Villegas, V.E.; Rondon-Lagos, M.; Annaratone, L.; Castellano, I.; Grismaldo, A.; Sapino, A.; Zaphiropoulos, P.G. Tamoxifen Treatment of Breast Cancer Cells: Impact on Hedgehog/GLI1 Signaling. Int. J. Mol. Sci. 2016, 17, 308. [CrossRef]

113. Po, A.; Silvano, M.; Miele, E.; Capalbo, C.; Eramo, A.; Salvati, V.; Todaro, M.; Besharat, Z.M.; Catanzaro, G.; Cucchi, D.; et al Noncanonical GLI1 signaling promotes stemness features and in vivo growth in lung adenocarcinoma. Oncogene 2017, 36, 4641-4652. [CrossRef] [PubMed]

114. Borah, A.; Raveendran, S.; Rochani, A.; Maekawa, T.; Kumar, D.S. Targeting self-renewal pathways in cancer stem cells: Clinical implications for cancer therapy. Oncogenesis 2015, 4, e177. [CrossRef] [PubMed]

115. Zhu, R.; Gires, O.; Zhu, L.; Liu, J.; Li, J.; Yang, H.; Ju, G.; Huang, J.; Ge, W.; Chen, Y.; et al. TSPAN8 promotes cancer cell stemness via activation of sonic Hedgehog signaling. Nat. Commun. 2019, 10, 2863. [CrossRef] [PubMed]

116. Clement, V.; Sanchez, P.; de Tribolet, N.; Radovanovic, I.; Altaba, A.R.I. HEDGEHOG-GLI1 signaling regulates human glioma growth, cancer stem cell self-renewal, and tumorigenicity. Curr. Biol. 2007, 17, 165-172. [CrossRef] [PubMed]

117. Nath, S.; Mondal, S.; Butti, R.; Prasanna Gunasekaran, V.; Chatterjee, U.; Halder, A.; Kundu, G.C.; Mandal, C. Desialylation of Sonic-Hedgehog by Neu2 Inhibits Its Association with Patched1 Reducing Stemness-Like Properties in Pancreatic Cancer Sphere-forming Cells. Cells 2020, 9, 1512. [CrossRef] [PubMed]

118. Chambers, I. The molecular basis of pluripotency in mouse embryonic stem cells. Cloning Stem Cells 2004, 6, 386-391. [CrossRef]

119. Zhou, J.; Wulfkuhle, J.; Zhang, H.; Gu, P.; Yang, Y.; Deng, J.; Margolick, J.B.; Liotta, L.A.; Petricoin, E., 3rd; Zhang, Y. Activation of the PTEN/mTOR/STAT3 pathway in breast cancer stem-like cells is required for viability and maintenance. Proc. Natl. Acad. Sci. USA 2007, 104, 16158-16163. [CrossRef]

120. Kaowinn, S.; Kaewpiboon, C.; Koh, S.S.; Kramer, O.H.; Chung, Y.H. STAT1HDAC4 signaling induces epithelialmesenchymal transition and sphere formation of cancer cells overexpressing the oncogene, CUG2. Oncol. Rep. 2018, 40, 2619-2627. [CrossRef]

121. Dey, N.; De, P.; Leyland-Jones, B. PI3K-AKT-mTOR inhibitors in breast cancers: From tumor cell signaling to clinical trials. Pharm. 2017, 175, 91-106. [CrossRef]

122. Tan, A.C. Targeting the PI3K/Akt/mTOR pathway in non-small cell lung cancer (NSCLC). Thorac. Cancer 2020, 11, 511-518. [CrossRef]

123. Fitzgerald, T.L.; Lertpiriyapong, K.; Cocco, L.; Martelli, A.M.; Libra, M.; Candido, S.; Montalto, G.; Cervello, M.; Steelman, L.; Abrams, S.L.; et al. Roles of EGFR and KRAS and their downstream signaling pathways in pancreatic cancer and pancreatic cancer stem cells. Adv. Biol Regul 2015, 59, 65-81. [CrossRef] [PubMed]

124. Madsen, R.R. PI3K in stemness regulation: From development to cancer. Biochem. Soc. Trans. 2020, 48, 301-315. [CrossRef] [PubMed]

125. Ouspenskaia, T.; Matos, I.; Mertz, A.F.; Fiore, V.F.; Fuchs, E. WNT-SHH Antagonism Specifies and Expands Stem Cells prior to Niche Formation. Cell 2016, 164, 156-169. [CrossRef] [PubMed]

126. Wahlster, L.; Daley, G.Q. Progress towards generation of human haematopoietic stem cells. Nat. Cell Biol. 2016, $18,1111-1117$. [CrossRef]

127. Kitaeva, K.V.; Rutland, C.S.; Rizvanov, A.A.; Solovyeva, V.V. Cell Culture Based in vitro Test Systems for Anticancer Drug Screening. Front. Bioeng. Biotechnol. 2020, 8, 322. [CrossRef]

128. Mani, S.A.; Guo, W.; Liao, M.J.; Eaton, E.N.; Ayyanan, A.; Zhou, A.Y.; Brooks, M.; Reinhard, F.; Zhang, C.C.; Shipitsin, M.; et al. The epithelial-mesenchymal transition generates cells with properties of stem cells. Cell 2008, 133, 704-715. [CrossRef]

129. Nieto, M.A.; Huang, R.Y.J.; Jackson, R.A.; Thiery, J.P. EMT: 2016. Cell 2016, 166, 21-45. [CrossRef]

130. Lambert, A.W.; Weinberg, R.A. Linking EMT programmes to normal and neoplastic epithelial stem cells. Nat. Rev. Cancer 2021, 21, 325-338. [CrossRef]

131. Liu, Y.; Nenutil, R.; Appleyard, M.V.; Murray, K.; Boylan, M.; Thompson, A.M.; Coates, P.J. Lack of correlation of stem cell markers in breast cancer stem cells. Br. J. Cancer 2014, 110, 2063-2071. [CrossRef] 
132. Karin, M.; Clevers, H. Reparative inflammation takes charge of tissue regeneration. Nature 2016, 529, 307-315. [CrossRef]

133. Zhang, M.; Xu, C.; Wang, H.Z.; Peng, Y.N.; Li, H.O.; Zhou, Y.J.; Liu, S.; Wang, F.; Liu, L.; Chang, Y.; et al. Soft fibrin matrix downregulates DAB2IP to promote Nanog-dependent growth of colon tumor-repopulating cells. Cell Death Dis 2019, 10, 151. [CrossRef]

134. Li, Y.; Wang, L.; Pappan, L.; Galliher-Beckley, A.; Shi, J. IL-1beta promotes stemness and invasiveness of colon cancer cells through Zeb1 activation. Mol. Cancer 2012, 11, 87. [CrossRef] [PubMed]

135. Hong, H.S.; Akhavan, J.; Lee, S.H.; Kim, R.H.; Kang, M.K.; Park, N.H.; Shin, K.H. Proinflammatory cytokine TNFalpha promotes HPV-associated oral carcinogenesis by increasing cancer stemness. Int. J. Oral Sci. 2020, 12, 3. [CrossRef]

136. Ciardiello, C.; Leone, A.; Budillon, A. The Crosstalk between Cancer Stem Cells and Microenvironment Is Critical for Solid Tumor Progression: The Significant Contribution of Extracellular Vesicles. Stem Cells Int. 2018, 2018, 6392198. [CrossRef] [PubMed]

137. Tam, S.Y.; Wu, V.W.C.; Law, H.K.W. Hypoxia-Induced Epithelial-Mesenchymal Transition in Cancers: HIF-1 alpha and Beyond. Front. Oncol. 2020, 10, 486. [CrossRef] [PubMed]

138. Ayob, A.Z.; Ramasamy, T.S. Cancer stem cells as key drivers of tumour progression. J. Biomed. Sci. 2018, 25, 20. [CrossRef]

139. Brosicke, N.; Faissner, A. Role of tenascins in the ECM of gliomas. Cell Adhes. Migr. 2015, 9, 131-140. [CrossRef]

140. Winer, J.P.; Janmey, P.A.; McCormick, M.E.; Funaki, M. Bone marrow-derived human mesenchymal stem cells become quiescent on soft substrates but remain responsive to chemical or mechanical stimuli. Tissue Eng. Part. A 2009, 15, 147-154. [CrossRef]

141. You, Y.; Zheng, Q.; Dong, Y.; Xie, X.; Wang, Y.; Wu, S.; Zhang, L.; Wang, Y.; Xue, T.; Wang, Z.; et al. Matrix stiffness-mediated effects on stemness characteristics occurring in HCC cells. Oncotarget 2016, 7, 32221-32231. [CrossRef]

142. Levental, K.R.; Yu, H.; Kass, L.; Lakins, J.N.; Egeblad, M.; Erler, J.T.; Fong, S.F.; Csiszar, K.; Giaccia, A.; Weninger, W.; et al. Matrix crosslinking forces tumor progression by enhancing integrin signaling. Cell 2009, 139, 891-906. [CrossRef]

143. Chulpanova, D.S.; Kitaeva, K.V.; James, V.; Rizvanov, A.A.; Solovyeva, V.V. Therapeutic Prospects of extracellular vesicles in Cancer Treatment. Front. Immunol. 2018, 9, 1534. [CrossRef] [PubMed]

144. Shaimardanova, A.A.; Solovyeva, V.V.; Chulpanova, D.S.; James, V.; Kitaeva, K.V.; Rizvanov, A.A. Extracellular vesicles in the diagnosis and treatment of central nervous system diseases. Neural Regen. Res. 2020, 15, 586-596. [CrossRef] [PubMed]

145. Bronisz, A.; Wang, Y.; Nowicki, M.O.; Peruzzi, P.; Ansari, K.I.; Ogawa, D.; Balaj, L.; De Rienzo, G.; Mineo, M.; Nakano, I.; et al. Extracellular Vesicles Modulate the Glioblastoma Microenvironment via a Tumor Suppression Signaling Network Directed by miR-1. Cancer Res. 2014, 74, 738-750. [CrossRef]

146. Hu, Y.B.; Yan, C.; Mu, L.; Huang, K.Y.; Li, X.L.; Tao, D.D.; Wu, Y.Q.; Qin, J.C. Fibroblast-Derived Exosomes Contribute to Chemoresistance through Priming Cancer Stem Cells in Colorectal Cancer. PLoS ONE 2015, 10, e0125625. [CrossRef] [PubMed]

147. Gonzalez, E.; Piva, M.; Rodriguez-Suarez, E.; Gil, D.; Royo, F.; Elortza, F.; Falcon-Perez, J.M.; Vivanco, M. Human mammospheres secrete hormone-regulated active extracellular vesicles. PLoS ONE 2014, 9, e83955. [CrossRef]

148. Gilazieva, Z.; Ponomarev, A.; Rutland, C.; Rizvanov, A.; Solovyeva, V. Promising Applications of Tumor Spheroids and Organoids for Personalized Medicine. Cancers 2020, 12, 2727. [CrossRef]

149. Jensen, C.; Teng, Y. Is It Time to Start Transitioning From 2D to 3D Cell Culture? Front. Mol. Biosci. 2020, 7, 33. [CrossRef]

150. Ishiguro, T.; Ohata, H.; Sato, A.; Yamawaki, K.; Enomoto, T.; Okamoto, K. Tumor-derived spheroids: Relevance to cancer stem cells and clinical applications. Cancer Sci. 2017, 108, 283-289. [CrossRef]

151. Djordjevic, B.; Lange, C.S. Clonogenicity of mammalian cells in hybrid spheroids: A new assay method. Radiat. Env. Biophys. 1990, 29, 31-46. [CrossRef]

152. Mikhail, A.S.; Eetezadi, S.; Allen, C. Multicellular tumor spheroids for evaluation of cytotoxicity and tumor growth inhibitory effects of nanomedicines in vitro: A comparison of docetaxel-loaded block copolymer micelles and Taxotere(R). PLoS ONE 2013, 8, e62630. [CrossRef]

153. Zhang, C.Y.; Yang, Z.T.; Dong, D.L.; Jang, T.S.; Knowles, J.C.; Kim, H.W.; Jin, G.Z.; Xuan, Y.H. 3D culture technologies of cancer stem cells: Promising ex vivo tumor models. J. Tissue Eng. 2020, 11. [CrossRef] [PubMed]

154. Drost, J.; Clevers, H. Organoids in cancer research. Nat. Rev. Cancer 2018, 18, 407-418. [CrossRef] [PubMed]

155. Papapetrou, E.P. Patient-derived induced pluripotent stem cells in cancer research and precision oncology. Nat. Med. 2016, 22, 1392-1401. [CrossRef] [PubMed]

156. Morrison, S.J.; Spradling, A.C. Stem cells and niches: Mechanisms that promote stem cell maintenance throughout life. Cell 2008, 132, 598-611. [CrossRef] [PubMed]

157. Hirschhaeuser, F.; Menne, H.; Dittfeld, C.; West, J.; Mueller-Klieser, W.; Kunz-Schughart, L.A. Multicellular tumor spheroids: An underestimated tool is catching up again. J. Biotechnol. 2010, 148, 3-15. [CrossRef]

158. Kahlert, U.D.; Mooney, S.M.; Natsumeda, M.; Steiger, H.J.; Maciaczyk, J. Targeting cancer stem-like cells in glioblastoma and colorectal cancer through metabolic pathways. Int. J. Cancer 2017, 140, 10-22. [CrossRef]

159. Puls, T.J.; Tan, X.H.; Whittington, C.F.; Voytik-Harbin, S.L. 3D collagen fibrillar microstructure guides pancreatic cancer cell phenotype and serves as a critical design parameter for phenotypic models of EMT. PLoS ONE 2017, 12, e0188870. [CrossRef]

160. Pal, A.; Ashworth, J.C.; Collier, P.; Probert, C.; Jones, S.; Leza, E.P.; Meakin, M.L.; Ritchie, A.A.; Onion, D.; Clarke, P.A.; et al. A 3D Heterotypic Breast Cancer Model Demonstrates a Role for Mesenchymal Stem Cells in Driving a Proliferative and Invasive Phenotype. Cancers 2020, 12, 2290. [CrossRef] 
161. Xue, J.G.; Zhu, Y.; Sun, Z.X.; Ji, R.B.; Zhang, X.; Xu, W.R.; Yuan, X.; Zhang, B.; Yan, Y.M.; Yin, L.; et al. Tumorigenic hybrids between mesenchymal stem cells and gastric cancer cells enhanced cancer proliferation, migration and stemness. BMC Cancer 2015, 15, 793. [CrossRef]

162. Nath, S.; Devi, G.R. Three-dimensional culture systems in cancer research: Focus on tumor spheroid model. Pharmacol. Ther. 2016, 163, 94-108. [CrossRef]

163. Maliszewska-Olejniczak, K.; Brodaczewska, K.K.; Bielecka, Z.F.; Solarek, W.; Kornakiewicz, A.; Szczylik, C.; Porta, C.; Czarnecka, A.M. Development of extracellular matrix supported 3D culture of renal cancer cells and renal cancer stem cells. Cytotechnology 2019, 71, 149-163. [CrossRef] [PubMed]

164. Gupta, P.B.; Onder, T.T.; Jiang, G.Z.; Tao, K.; Kuperwasser, C.; Weinberg, R.A.; Lander, E.S. Identification of Selective Inhibitors of Cancer Stem Cells by High-Throughput Screening. Cell 2009, 138, 645-659. [CrossRef] [PubMed]

165. Namiki, K.; Wongsirisin, P.; Yokoyama, S.; Sato, M.; Rawangkan, A.; Sakai, R.; Iida, K.; Suganuma, M. (-)-Epigallocatechin gallate inhibits stemness and tumourigenicity stimulated by AXL receptor tyrosine kinase in human lung cancer cells. Sci Rep. 2020, 10, 2444. [CrossRef] [PubMed]

166. Prasad, S.; Rarnachandran, S.; Gupta, N.; Kaushik, I.; Srivastava, S.K. Cancer cells stemness: A doorstep to targeted therapy. Biochim. Biophys. Acta-Mol. Basis Dis. 2020, 1866. [CrossRef]

167. Konishi, J.; Kawaguchi, K.S.; Vo, H.; Haruki, N.; Gonzalez, A.; Carbone, D.P.; Dang, T.P. gamma-secretase inhibitor prevents Notch3 activation and reduces proliferation in human lung cancers. Cancer Res. 2007, 67, 8051-8057. [CrossRef]

168. Moore, G.; Annett, S.; McClements, L.; Robson, T. Top Notch Targeting Strategies in Cancer: A Detailed Overview of Recent Insights and Current Perspectives. Cells 2020, 9, 1503. [CrossRef]

169. Cook, N.; Basu, B.; Smith, D.M.; Gopinathan, A.; Evans, J.; Steward, W.P.; Palmer, D.; Propper, D.; Venugopal, B.; Hategan, M.; et al. A phase I trial of the gamma-secretase inhibitor MK-0752 in combination with gemcitabine in patients with pancreatic ductal adenocarcinoma. Br. J. Cancer 2018, 118, 793-801. [CrossRef]

170. Herman, S.E.M.; Gordon, A.L.; Wagner, A.J.; Heerema, N.A.; Zhao, W.Q.; Flynn, J.M.; Jones, J.; Andritsos, L.; Puri, K.D.; Lannutti, B.J.; et al. Phosphatidylinositol 3-kinase-delta inhibitor CAL-101 shows promising preclinical activity in chronic lymphocytic leukemia by antagonizing intrinsic and extrinsic cellular survival signals. Blood 2010, 116, 2078-2088. [CrossRef]

171. Foster, P.; Yamaguchi, K.; Hsu, P.P.; Qian, F.; Du, X.N.; Wu, J.M.; Won, K.A.; Yu, P.W.; Jaeger, C.T.; Zhang, W.T.; et al. The Selective PI3K Inhibitor XL147 (SAR245408) Inhibits Tumor Growth and Survival and Potentiates the Activity of Chemotherapeutic Agents in Preclinical Tumor Models. Mol. Cancer Ther. 2015, 14, 931-940. [CrossRef]

172. Eyler, C.E.; Foo, W.C.; Lafiura, K.M.; McLendon, R.E.; Hjelmeland, A.B.; Rich, J.N. Brain Cancer Stem Cells Display Preferential Sensitivity to Akt Inhibition. Stem Cells 2008, 26, 3027-3036. [CrossRef]

173. Pal, S.K.; Reckamp, K.; Yu, H.; Figlin, R.A. Akt inhibitors in clinical development for the treatment of cancer. Expert Opin. Investig. Drugs 2010, 19, 1355-1366. [CrossRef]

174. Tagawa, S.T.; Chatta, G.S.; Mazhari, R.; Benaim, E. Archexin, a novel AKT-1-specific inhibitor for the treatment of metastatic renal cancer: Preliminary phase I data. J. Clin. Oncol. 2016, 34. [CrossRef]

175. Lindemann, R.K. Stroma-initiated hedgehog signaling takes center stage in B-cell lymphoma. Cancer Res. 2008, 68, 961-964. [CrossRef] [PubMed]

176. Jimeno, A.; Gordon, M.; Chugh, R.; Messersmith, W.; Mendelson, D.; Dupont, J.; Stagg, R.; Kapoun, A.M.; Xu, L.; Uttamsingh, S.; et al. A First-in-Human Phase I Study of the Anticancer Stem Cell Agent Ipafricept (OMP-54F28), a Decoy Receptor for Wnt Ligands, in Patients with Advanced Solid Tumors. Clin. Cancer Res. 2017, 23, 7490-7497. [CrossRef] [PubMed]

177. Ko, A.H.; Chiorean, E.G.; Kwak, E.L.; Lenz, H.J.; Nadler, P.I.; Wood, D.L.; Fujimori, M.; Inada, T.; Kouji, H.; McWilliams, R.R Final results of a phase $\mathrm{Ib}$ dose-escalation study of PRI-724, a CBP/beta-catenin modulator, plus gemcitabine (GEM) in patients with advanced pancreatic adenocarcinoma (APC) as second-line therapy after FOLFIRINOX or FOLFOX. J. Clin. Oncol. 2016, 34. [CrossRef]

178. Cortes, J.E.; Faderl, S.; Pagel, J.; Jung, C.W.; Yoon, S.S.; Koh, Y.; Pardanani, A.D.; Hauptschein, R.S.; Lee, K.J.; Lee, J.H. Phase 1 study of CWP232291 in relapsed/refractory acute myeloid leukemia (AML) and myelodysplastic syndrome (MDS). J. Clin. Oncol. 2015, 33. [CrossRef]

179. Jonker, D.J.; Stephenson, J.; Edenfield, W.J.; Supko, J.G.; Li, Y.Z.; Li, W.; Hitron, M.; Leggett, D.; Kerstein, D.; Li, C. A phase I extension study of BBI608, a first-in-class cancer stein cell (CSC) inhibitor, in patients with advanced solid tumors. J. Clin. Oncol. 2014, 32. [CrossRef]

180. Laurie, S.A.; Jonker, D.J.; Edenfield, W.J.; Stephenson, J.; Keller, D.; Hitron, M.; Li, W.; Li, Y.Z.; Gada, K.; Gao, Y.; et al. A phase 1 dose-escalation study of BBI503, a first-in-class cancer stemness kinase inhibitor in adult patients with advanced solid tumors. J. Clin. Oncol. 2014, 32. [CrossRef] 